\title{
В ПОИСКЕ
} оптимального пути развития

Л.Павлова

DOI: 10.22184/2070-8963.2017.66.5.40.41

Год знаменательных для спутниковой связи дат - 60-летия вывода на орбиту первого в мире искусственного спутника Земли, 50-летия запуска первой в СССР сети спутниковой связи "Орбита" и полувекового юбилея ГП КС - стал и периодом напряженного поиска новых путей развития.

\section{В РЕАЛИЯХ ПРОФИЦИТА ЕМКОСТИ}

Как сообщил в своем выступлении на IX Международной конференции Satellite Russia \& CIS 2017 заместитель руководителя Россвязи Игорь Чурсин, в настоящее время идет активная реализация ФЦП по развитию новой спутниковой группировки: подписаны контракты на создание двух космических аппаратов ГП КС, запуск которых на геостационарную орбиту заплани рован на 2019 год; ведется работа по подписа нию контрактов на производство еще трех КА; методично и скрупулезно прорабатывается концепция создания системы спутниковой связи из четырех космических аппаратов на высокоэллиптической орбите для обеспечения связью северных широт. Говоря о роли ФГУП "Космическая связь" в спутниковой отрасли, И.Чурсин отметил: "Космические аппараты российского государственного оператора спутниковой связи обеспечивают глобальное покрытие, предприятие входит в десятку крупнейших спутниковых операторов мира по объему орбитально-частотного ресурса и обладает опытом создания и эксплуатации спутниковых систем связи и вещания в интересах государственных и коммерческих пользователей на территории Российской Федерации и большинства стран мира".

Вместе с тем, как сообщил замглавы Россвязи, в 2016 году была зафиксирована отрицательная динамика развития спутниковой отрасли $(-7,3 \%)$, следствием чего для операторов спутниковой связи ближайшее пятилетие станет периодом замед ления роста доходов. "Прошедший год заставил всех спутниковых операторов в той или иной мере пересмотреть стратегию своего развития и искать выходы на новые рынки, - констатировал И.Чурсин. - Операторы все больше внимания уделяют гибкости активов - объявляют о создании комбинированных группировок геостационар ных и низкоорбитальных космических аппаратов. Отрасли совместно с иностранными партнерами предстоит большая и напряженная работа по всем направлениям в интересах экономики и сохранения лидерства страны".

Спутниковая связь оказалась в сложной ситуа ции. С одной стороны, по словам генерального директора ОАО "Газпром космические системы" Дмитрия Севастьянова, появление новых спут ников с высокой пропускной способностью (HTS) и резко обострившаяся конкуренция привели к образованию профицита емкости, что, в свою очередь, стало причиной падения цен на спутниковый ресурс на 20-30\%. Но с другой - рост потребностей в информационных потоках в глобальном масштабе между несколькими миллиардами стационарных и мобильных объектов и устройств - хорошая основа для развития индустрии спутниковой связи, считает глава ГКС. При этом будут востребованы и традиционные спутники, и системы с высокой пропускной способностью, работающие на новых частотах.

По мнению генерального директора ФГУП "Космическая связь" Юрия Прохорова, сейчас рынок спутниковой связи можно охарактеризовать в целом как находящийся "в зоне сингулярности", когда никто не даст однозначного ответа на вопрос, что же будет завтра, но все пребывают в поиске оптимального пути развития. При этом поиск затруднен многосторонней нестабильностью. "Впрочем, на фоне серьезного падения 
акций крупнейших спутниковых операторов оценка экономического состояния ГП КС очень позитивная, отсутствуют признаки финансовой несостоятельности или банкротства - и это радует", - признал Ю.Прохоров.

\section{ПЕРСПЕКТИВА В ДВИЖЕНИИ}

К одному из перспективных направлений развития спутниковой связи можно отнести СОТМ (Communication On The Move) - связь с подвижными объектами. По данным Сергея Пехтерева, советника генерального директора ЗАО "Рэйс Телеком" (ГK AltegroSky), этот сегмент уверенно растет, и к концу 2025 года ему будет принадлежать около 16\% от общего потребления спутниковой емкости. Самый крупный потребитель в этом сегменте - морской и речной транспорт, второй по объемам потребления - авиаперевозки. При этом, по словам С.Пехтерева, в отличие от традиционных рынков фиксированной спутниковой связи, где успешным мог быть региональный оператор, на рынке подвижной связи рассчитывать на получение клиентов может только оператор с глобальным покрытием - и оптимальной стратегией для российских операторов будет заключение альянсов с мировыми глобальными игроками и обмен инфраструктурных услуг на услуги СОТМ для российских перевозчиков за пределами России.

Что касается услуг спутниковой связи на железнодорожном транспорте, то их развитие в России тормозится рядом факторов. По мнению заместителя руководителя Центра инновационных спутниковых технологий ОАО "НИИАС" Владислава Тамаркина, основной технической проблемой спутникового интернета в поездах в России является наличие больших участков пути, проложенных вдоль лесных массивов, которые создают серьезные помехи при приеме сигнала с геостационарных КА. Не менее серьезной участники рынка признают проблему организационную. Как сообщил генеральный директор OOO "Гилат Сателлайт Нетворкс (Евразия)" (Gilat Satellite Networks) Александр Климов, еще два года назад компания провела испытания своего оборудования на российских поездах - и интернет работал отлично. Однако практическая реализация проекта остановилась из-за отсутствия на рынке оператора, готового его осуществить. По мнению директора по продажам в РФ представительства Hughes Network Systems Юрия Фомина, проблема может быть решена путем создания специализированных сервисных компаний, тогда как согласование размещения оборудования в каждом поезде с ОАО "РЖД" становится сложным и трудоемким процессом, тормозящим внедрение спутникового ШПД на железнодорожном транспорте.

K вопросам организации высокоскоростного доступа в интернет в скоростных поездах подключилась Минкомсвязь России. Как сообщил Александр Егоров, начальник отдела специальных проектов Департамента инфраструктурных проектов Министерства связи и массовых коммуникаций, в рамках поручения председателя Государственной комиссии по подготовке и празднованию 100-летия образования Республики Карелия, Секретаря Совета Безопасности РФ Николая Патрушева министерство рассматривает возможность обеспечения высокоскоростным доступом пассажиров четырех поездов "Ласточка" Петрозаводск- Санкт-Петербург. Минкомсвязь прорабатывает этот вопрос с ОАО "РЖД": совместно определены требования к каналам связи, изучены возможности использования как наземных сетей, так и VSAT-технологии. "ОАО "РЖД" очень настороженно относится к Кu-диапазону, потому что это дорого, но в отношении Ка-диапазона проявили некоторую заинтересованность, - рассказал А.Егоров. - Однако по результатам проработки было выявлено, что для Ка-диапазона отсутствует решение ГКРЧ для земных станций, которые установлены на подвижных объектах, и мы планируем, что в третьем квартале 2017 года это решение будет принято".

В целом, как заметил Константин Ланин, глава представительства, региональный директор Hughes Network Systems, интерес к связи на подвижных объектах растет и требует гибких технологических решений, способных качественно и эффективно удовлетворить жесткие требования различных сегментов рынка, а также содействовать реализации разнообразных бизнесмоделей. Например, Hughes совместно с компанией Gilat выпустили авиационную антенну Ku/ Ка-диапазона, которая совместима с любыми системами. При этом, по наблюдению К.Ланина, в России "большая четверка" операторов сотовой связи практически не использует спутниковые технологии, и этот потенциальный рынок еще не развит должным образом. А главной проблемой, как и во многих других странах, остается инерция представления людей, что спутниковая связь- это медленно и дорого. И это тоже кризис, не экономический или технологический, а кризис восприятия. 